\title{
Association between work-related health problems and job insecurity in permanent and temporary employees
}

Won-Wook Lee', Jae-Bum Park ${ }^{2 *}$, Kyoung-Bok Min², Kyung-Jong Lee ${ }^{2}$ and Min-Su Kim

\begin{abstract}
Objectives: This research was conducted with an aim of determining the correlation between job insecurity and an employee's work-related health problems among permanent and temporary workers.

Methods: Using the data from the First Korean Working Conditions Survey conducted in 2006, a total of 7,071 workers, excluding employers and the self-employed, were analyzed. Work-related health problems were categorized as backache, headache, abdominal pain, muscular pain, stress, fatigue, insomnia, anxiety or depression. Each problem was then analyzed for its relationship to job insecurity through logistic regression analysis.

Results: Among the 7,071 workers, 5,294 (74.9\%) were permanent workers and 1,777 (25.1\%) were temporary workers. For the permanent workers, presence of high or moderate job insecurity appeared more closely linked to backache, headache, abdominal pain, muscular pain, stress, fatigue, insomnia, anxiety, and depression compared to absence of job insecurity. However, for the temporary workers, only depression appeared to be associated with the presence of high job insecurity.

Conclusion: The study showed that the presence of job insecurity is correlated with work-related health problems. The deleterious effects of job insecurity appeared to be stronger in permanent than temporary workers. Additional research should investigate ways to effectively reduce job insecurity.
\end{abstract}

Keywords: Job insecurity, Work-related health problems, Permanent workers, Temporary workers, Korean working conditions survey

\section{Introduction}

As a type of occupational stress, job insecurity has been defined in a number of ways, from concerns about maintaining a current job or work position, fear of total loss of any type of employment, to a degree of concern about the extent of job security [1-3]. All of these varying definitions are based upon the uncertain future and the individual experiences of workers [4]. Job insecurity, in effect, is a perception, and is different from the threat of losing one's job or the actual dismissal from the employment because, employees are apt to experience this with or without the true risk of such losses [3]. Even though it is generally known that temporary employees

\footnotetext{
* Correspondence: jbpark@ajou.ac.kr

${ }^{2}$ Department of Occupational and Environmental Medicine, Ajou University School of Medicine, Suwon, South Korea

Full list of author information is available at the end of the article
}

experience more job insecurity than do permanent ones, it is always possible for permanent employees, who are less likely to actually be dismissed from work, to perceive job insecurity as a threat throughout their employment just as temporary employees do, and because more employees are likely to experience such threat than actually experience dismissals, job insecurity has become an important occupational stress factor $[4,5]$.

Within the most recent few decades, a pan-global economic crisis has caused many corporations and companies to carry out restructuring, mergers, etc., and this brought about massive layouts and expansion of temporary employment in the secondary labor market, which has exposed an increasing number of workers to the perception of job insecurity [6]. Hence, reports and studies generally identify such job insecurity as contributing negatively to the psychological and physical health and well-being of 
employees [1,3,7-12]. Up until now, studies in South Korea (hereafter, "Korea"), however, have treated job insecurity along the dame lines as actual job losses, threats of job dismissal, and/or temporary employment [13], and some have limited their subjects to a certain job group [10-12]. Furthermore, even though reports from other countries indicate different correlations between the health of the employees and the job insecurity according to different types of employment $[14,15]$, research on how job insecurity impacts different types of workers has been sparse in Korea.

There are two hypotheses that have to do with the type of employment and job insecurity. The intensification hypothesis explains that the perception of job insecurity of temporary employees contributes to more health problems than permanent employees' experience. On the other hand, the violation hypothesis explains that even though temporary employees experience more job losses and risks than permanent employees, permanent employees' perception of job insecurity causes more detrimental health issues $[14,16]$. In many studies outside of Korea, evidence has been gathered that supports the latter claim [15,17-19], but the results have only been found in some countries [14], and they were focused more on the psychological dimension [15]. Moreover, the research on both the physical and psychological health effects of job insecurity on workers did not show a significant association with job insecurity $[20,21]$.

Our research, using the First Korean Working Conditions Survey (2006), aims to evaluate the hypothesis mentioned earlier, that job insecurity correlates to the health and well-being of employees, and goes on to determine the differences in work-related health and well-being according to the differing perceptions of job insecurity between two types of employees.

\section{Materials and methods Study population}

Our research utilized the First Korean Working Conditions Survey, which was published in 2006. This survey was performed by the Occupational Safety and Health Research Institute (OSHRI), and was based on the Fourth European Working Conditions Survey. With an intent to set up all employees residing in South Korea as a cohort, the survey collected general information such as gender, age, lifestyle, and work environment factors such as occupation, area of specialty, type of employment, noxious exposure, and the shift system in order to acknowledge the extent of exposure of risk factors having to do with work environment and to provide appropriate information for policy. Paid employees from the age of 15 to 64 were included, and based on the 2005 Korea Population and Housing Census as a sampling frame, survey units were selected and trained surveyors visited each household to carry out the survey [22]. Out of a total number of 10,043 participants, with the exclusion of the self-employed, employers and those who did not complete with essential parts of the survey, 7,071 were selected as the study population. This study was reviewed by the institutional review board (IRB) of Ajou University Hospital.

\section{Study design}

We have defined the group of participants with high job insecurity as those who have responded to the statement of the First Korean Working Conditions Survey (2006), "I will lose my job within the next 6 months" with "Agree" or "Very much agree", those who reported themselves to be "Neutral" as a moderate job insecurity group, and those who answered "Disagree" and "Strongly disagree" as a low job insecurity group. Those who responded "yes "to the question "Have you ever had any hazardous accidents or health problems on account of your job?" and selected any one of backache, headache, abdominal pain, muscular pain (shoulder, neck, or upper or lower extremities), stress, fatigue, sleeping problems, anxiety, or depression as the health problem derived from the employment were defined as having work-related health problems. The participants who reported having one or more symptoms of backache, headache, abdominal pain, muscular pain, or fatigue were treated as a physical health problem group, and those with one or more of stress, sleeping problems, anxiety, or depression were considered to have psychological health problems. In addition, in order to determine the influence of hazardous exposure and work environment on the health of the employees, those who responded affirmatively to one or more of the queries on physical/chemical hazard exposure or ergonomic risk factor exposure for more than half of the working time were defined as an exposure group. The workers were also classified by contract type [22], into permanent and temporary employees. Permanent employees were defined as those who were employed full-time either indefinitely or with a limited contract period with a continuous working period of one year or more, and all the rest of the workers were classified as temporary employees.

\section{Statistical analysis}

Our research was conducted, stratifying by employment type, to find the association between social demographic characteristics as well as work environment factors, on the one hand, and the level of job insecurity and work-related health problems, both physical and psychological, on the other. Then, adjusting for factors such as demographic characteristics and work environment, logistic regression was performed. Statistical analysis was done using Statistical Package for the Social Science (SPSS) for Windows version 19.0 (IBM Corp.: Armonk, NY, USA). 


\section{Results}

\section{General characteristics}

The total number of employees included in the study was 7,071 . Among them, 6,248 (88.4\%) had low job insecurity, 446 (6.3\%) moderate, and 377 (5.3\%) high. Of the characteristics based on the different levels of job insecurity, the age of those with a high level of insecurity ranged from 25 to 54 years old, and those with low insecurity were mostly younger than 24 and over 55 years old. By gender, women had a higher sense of job insecurity than men. Those with lower job insecurity tended to have the group with a higher income, as well as a higher educational level. Regarding type of employment, the temporary employee group showed a higher level of job insecurity than the permanent ones did, with $11.6 \%$ and $11.1 \%$ reporting a moderate level and high level of job insecurity, respectively, while $4.5 \%$ and $3.4 \%$ of the permanent employees in the moderate and high level groups, respectively, reported job insecurity. The demographics also showed that physical laborers and those who were in the service industry had a higher incidence of moderate to high job insecurity than did those who were office clerks or professionals. Those who had moderate to high job insecurity were more likely to have more exposure to physical and/or chemical hazards or had higher ergonomic risk factors than not. Smoking, drinking, and the shift system, however, had no statistical significance among the different levels of job insecurity (Table 1).

\section{Work-related health problems and the level of job insecurity by contract type}

Work-related health was analyzed by stratifying participants into different contract types: temporary and permanent. The temporary employees reported more work-related health problems than did the permanent workers (data not shown). After the stratification, comparing work-related health problems at each level of job insecurity, it was found that permanent workers responded with more work-related health problems in higher level of job insecurity than those with low job insecurity. As for the temporary employees, even though there proved to be more complaints of work-related health problems compared to the permanent workers on the whole, unlike the permanent workers, the differences in work-related health problems by level of job insecurity were not statistically significant (Table 2).

\section{Correlation of job insecurity of each contract type with work-related health problems}

In order to examine the correlation between job insecurity and work-related health problems, multiple logistic regression was used according to contract type, adjusting for social demographic factors such as gender, age, education, income, occupation, smoking, and drinking, and work-related characteristics such as working hours, shift schedule, physical and chemical hazard exposure, and ergonomic risk factors. Analyzing only the temporary employees, those with higher job insecurity showed more correlation to having depression (OR 2.41; 95\% $\mathrm{CI}=1.24-4.68)$. Aside from that, there were no statistically significant associations between level of job insecurity and work-related health (Table 3). Unlike the temporary workers, however, the permanent employees with moderate job insecurity, compared to those with low, responded as having backache (OR 2.08; 95\% CI = 1.49-2.90), headache (OR 2.19; 95\% CI = 1.53-3.13), abdominal pain (OR 2.52; 95\% CI =1.66-3.81), muscular pain (OR 1.86; 95\% CI = $1.35-2.58$ ), fatigue (OR 2.12; $95 \% \mathrm{CI}=1.54-2.92$ ), stress (OR 1.97; 95\% CI = 1.44-2.68), sleeping problems (OR 3.04; $95 \% \mathrm{CI}=1.95-4.74)$, anxiety (OR $2.91 ; 95 \% \mathrm{CI}=1.82-4.65)$, and depression (OR 3.82; 95\% CI =2.34-6.23), all with statistical significance. The high job insecurity group also showed statistically significant results compared to those with low, reporting higher rates of backache (OR 1.78; 95\% $\mathrm{CI}=1.20-2.64$ ), headache (OR 1.91; 95\% CI=1.25-2.93), abdominal pain (OR 3.27; 95\% CI =2.09-5.12), muscular pain (OR 1.68; 95\% CI =1.14-2.46), fatigue (OR 1.75; 95\% $\mathrm{CI}=1.19-2.57)$, stress $(\mathrm{OR} 1.65 ; \quad 95 \% \quad \mathrm{CI}=1.14-2.40)$, sleeping problems (OR 2.31; 95\% CI $=1.33-4.02$ ), anxiety (OR 2.33; 95\% CI = 1.31-4.13), and depression (OR 2.26; $95 \% \mathrm{CI}=1.16-4.39$ ). Additional analysis of the physical and/or psychological health problems and all types of health problems showed a higher odds ratio in the group with higher job insecurity than in those with low job insecurity (Table 4).

\section{Discussion}

This study using the First Korean Working Conditions Survey data gathered in 2006, investigated the correlation between the level of job insecurity and work-related health problems among South Korean employees. In particular, stratifying according to contract type, analyses were performed to determined whether there were correlations between job insecurity and both the type of contract (temporary or permanent) and work-related health. On examination, a greater correlation with work-related health was found in the group with moderate or higher job insecurity in the permanent employees. The connection between health problems and job insecurity has been investigated in a variety of studies using either direct or indirect methods, and the majority of studies have reported that job insecurity has negative correlation to health $[1,5,7-9,18,23-26]$. In one study conducted with the employees of a major electronics company in South Korea, job insecurity was shown to affect psychological health in both male and female workers [12]. Another study on fire fighters and male employees of an automobile manufacturing corporation demonstrated that their depressive symptoms are linked to job insecurity [11]. Many 
Table 1 Characteristics of the participants

\begin{tabular}{|c|c|c|c|c|c|c|}
\hline \multirow{2}{*}{\multicolumn{2}{|c|}{ Variables }} & \multirow[t]{2}{*}{ All } & \multicolumn{3}{|c|}{ Job insecurity $N(\%)$} & \multirow[t]{2}{*}{ p-value* } \\
\hline & & & Low & \multirow{2}{*}{$\begin{array}{r}\text { Moderate } \\
446(6.3)\end{array}$} & High & \\
\hline Total & & 7,071 & $6,248(88.4)$ & & $377(5.3)$ & \\
\hline \multicolumn{7}{|c|}{ Age group (years) } \\
\hline & $15-24$ & 398 & $325(81.7)$ & $22(5.5)$ & $51(12.8)$ & $<0.001$ \\
\hline & $25-34$ & 2,016 & $1,786(88.6)$ & $134(6.6)$ & $96(4.8)$ & \\
\hline & $35-44$ & 2,506 & $2,244(89.5)$ & $149(5.9)$ & $113(4.5)$ & \\
\hline & $45-54$ & 1,473 & $1,331(90.4)$ & $77(5.2)$ & $65(4.4)$ & \\
\hline & $55-65$ & 678 & $562(82.9)$ & $64(9.4)$ & $52(7.7)$ & \\
\hline \multicolumn{7}{|c|}{ Gender } \\
\hline & Male & 4,594 & 4,083 (88.9) & $296(6.4)$ & $215(4.7)$ & 0.004 \\
\hline & Female & 2,477 & $2,165(87.4)$ & $150(6.1)$ & $162(6.5)$ & \\
\hline \multicolumn{7}{|c|}{ Income (10,000 won/month) } \\
\hline & $<100$ & 1,516 & 1,192 (78.6) & $161(10.6)$ & $163(10.8)$ & $<0.001$ \\
\hline & $100-200$ & 2,987 & 2,369 (88.3) & $200(6.7)$ & $148(5.0)$ & \\
\hline & $200-299$ & 1,663 & $1,552(93.3)$ & $66(4.0)$ & $45(2.7)$ & \\
\hline & $\geq 300$ & 905 & $865(95.6)$ & $19(2.1)$ & $21(2.3)$ & \\
\hline \multicolumn{7}{|c|}{ Education completed } \\
\hline & $\leq$ Middle school & 1,024 & $846(82.6)$ & $100(9.8)$ & $78(7.6)$ & $<0.001$ \\
\hline & High school & 2,915 & $2,522(86.5)$ & $199(6.8)$ & $194(6.7)$ & \\
\hline & $\geq$ University & 3,132 & $2,880(92.0)$ & $147(4.7)$ & $105(3.4)$ & \\
\hline \multicolumn{7}{|c|}{ Drinking (times/week) } \\
\hline & No drinking & 1,688 & $1,494(88.5)$ & $103(6.1)$ & $91(5.4)$ & 0.170 \\
\hline & $\leq 1$ & 3,084 & $2,722(88.3)$ & $182(5.9)$ & $180(5.8)$ & \\
\hline & $\geq 2$ & 2,299 & 2,032 (88.4) & $161(7.0)$ & $106(4.6)$ & \\
\hline \multicolumn{7}{|c|}{ Smoking } \\
\hline & Never & 3,627 & $3,188(87.9)$ & $228(6.3)$ & $211(5.8)$ & 0.162 \\
\hline & Former & 952 & $844(88.7)$ & $69(7.2)$ & $39(4.1)$ & \\
\hline & Current & 2,492 & $2,216(88.9)$ & $149(6.0)$ & $127(5.1)$ & \\
\hline \multicolumn{7}{|c|}{ Contract type } \\
\hline & Permanent & 5,294 & $4,875(92.1)$ & $240(4.5)$ & $179(3.4)$ & $<0.001$ \\
\hline & Temporary & 1,777 & $1,373(77.3)$ & $206(11.6)$ & $198(11.1)$ & \\
\hline \multicolumn{7}{|c|}{ Occupation } \\
\hline & Office clerk & 1,448 & $1,324(91.4)$ & $66(4.6)$ & $58(4.0)$ & $<0.001$ \\
\hline & Professional & 1,486 & $1,377(92.7)$ & $60(4.0)$ & $49(3.3)$ & \\
\hline & Service industry & 1,217 & $1,057(86.9)$ & $87(7.1)$ & $73(6.0)$ & \\
\hline & Physical labor & 2,920 & 2,490 (85.3) & $233(8.0)$ & $197(6.7)$ & \\
\hline \multicolumn{7}{|c|}{ Working hours per week } \\
\hline & $<35$ & 571 & $442(77.4)$ & $71(12.4)$ & $58(10.2)$ & $<0.001$ \\
\hline & $35-44$ & 2,649 & 2,413 (91.1) & $124(4.7)$ & $112(4.2)$ & \\
\hline & $\geq 45$ & 3,851 & 3,393 (88.1) & $251(6.5)$ & $207(5.4)$ & \\
\hline \multicolumn{7}{|c|}{ Work schedule } \\
\hline & Non-shift & 6,252 & $5,626(88.4)$ & $400(6.4)$ & $326(5.2)$ & 0.350 \\
\hline & Shift & 819 & $722(88.2)$ & $46(5.6)$ & $51(6.2)$ & \\
\hline
\end{tabular}


Table 1 Characteristics of the participants (Continued)

\begin{tabular}{|c|c|c|c|c|c|}
\hline \multicolumn{6}{|l|}{ Physical \& chemical hazards } \\
\hline Non-exposure & 4,451 & 4,044 (90.9) & $218(4.9)$ & $189(4.2)$ & \multirow[t]{2}{*}{$<0.001$} \\
\hline Exposure & 2,620 & 2,204 (84.1) & $228(8.7)$ & $188(7.2)$ & \\
\hline \multicolumn{6}{|l|}{ Ergonomic risk factors } \\
\hline Non-exposure & 1,964 & $1,803(91.8)$ & $93(4.7)$ & $68(3.5)$ & \multirow[t]{2}{*}{$<0.001$} \\
\hline Exposure & 5,107 & $4,445(87.0)$ & $353(6.9)$ & $309(6.1)$ & \\
\hline
\end{tabular}

*Calculated by chi-squared test.

other studies have reported similar results, such as a study on the relation between overweight and obesity, and job insecurity [8], and another on the association between job insecurity and subjective health perceptions and complaints of depressive symptoms. A study on insomnia incidence in relation to job insecurity also found similar results [9].

It is difficult to anticipate an appropriate action or provide timely social support for the phenomena that result from job insecurity, since it does not occur in an objective and distinctive manner such as actual unemployment or layoff [5]. In effect, in the case where job insecurity is experienced, it is often not easy for employees to find a way to work it out or find a solution, and in the end, the insecurity could materialize as chronic stress [3]. Our body, under a certain amount of stress, exudes hormones such as catecholamine, dopamine, serotonin, etc., following changes in the hypothalamus-pituitary-endocrine axis, limbic system, as well as autonomic nervous system-adrenal cortex [27]. These changes in hormones result in a variety of physical responses. For one, catecholamine can raise the blood pressure and heart rate, cause vasoconstriction of the vessels and hemodynamic changes, and activate

Table 2 Results of work related health problems by contract type and level of job insecurity

\begin{tabular}{|c|c|c|c|c|c|c|c|c|c|}
\hline \multirow[t]{2}{*}{ Variables } & & \multicolumn{3}{|c|}{$\begin{array}{c}\text { Permanent } \\
\text { Job insecurity }\end{array}$} & \multirow[t]{2}{*}{ p-value* } & \multicolumn{3}{|c|}{$\begin{array}{c}\text { Temporary } \\
\text { Job insecurity }\end{array}$} & \multirow[t]{2}{*}{ p-value* } \\
\hline & & Low & Moderate & $\overline{\text { High }}$ & & Low & Moderate & $\overline{\text { High }}$ & \\
\hline \multirow[t]{2}{*}{ All health problems } & No & $3,865(79.3)$ & $169(70.4)$ & $121(67.6)$ & $<0.001$ & $982(71.5)$ & $140(68.0)$ & $149(75.3)$ & 0.268 \\
\hline & Yes & $1,010(20.7)$ & $71(29.6)$ & $58(32.4)$ & & $391(28.5)$ & $66(32.0)$ & $49(24.7)$ & \\
\hline \multirow[t]{2}{*}{ Physical health problems } & No & $3,925(80.5)$ & $170(70.8)$ & $124(69.3)$ & $<0.001$ & $994(72.4)$ & $142(68.9)$ & $149(75.3)$ & 0.361 \\
\hline & Yes & $950(19.5)$ & $70(29.2)$ & $55(30.7)$ & & $379(27.6)$ & $64(31.1)$ & $49(24.7)$ & \\
\hline \multirow[t]{2}{*}{ Backache } & No & $4,296(88.1)$ & $185(77.1)$ & $142(79.3)$ & $<0.001$ & $1,101(80.2)$ & $155(75.2)$ & $160(80.8)$ & 0.415 \\
\hline & Yes & $579(11.9)$ & $55(22.9)$ & $37(20.7)$ & & $272(19.8)$ & $51(24.8)$ & $38(19.2)$ & \\
\hline \multirow[t]{2}{*}{ Headache } & No & $4,429(90.9)$ & $196(81.7)$ & $150(83.8)$ & $<0.001$ & $1,210(88.1)$ & $175(85.0)$ & $175(88.4)$ & 0.415 \\
\hline & Yes & $446(9.1)$ & $44(18.3)$ & $29(16.2)$ & & $163(11.9)$ & $31(15.0)$ & $23(11.6)$ & \\
\hline \multirow[t]{2}{*}{ Abdominal pain } & No & $4,617(94.7)$ & $209(87.1)$ & $151(84.4)$ & $<0.001$ & $1,280(93.2)$ & $191(92.7)$ & $183(92.4)$ & 0.896 \\
\hline & Yes & $258(5.3)$ & $31(12.9)$ & $28(15.6)$ & & $93(6.8)$ & $15(7.3)$ & $15(7.6)$ & \\
\hline \multirow[t]{2}{*}{ Muscular pain } & No & $4,211(86.4)$ & $183(76.3)$ & $139(77.7)$ & $<0.001$ & $1,071(78.0)$ & $152(73.8)$ & $153(77.3)$ & 0.401 \\
\hline & Yes & $664(13.6)$ & $57(23.8)$ & $40(22.3)$ & & $302(22.0)$ & $54(26.2)$ & $45(22.7)$ & \\
\hline \multirow[t]{2}{*}{ Fatigue } & No & $4,214(86.4)$ & $179(74.6)$ & $140(78.2)$ & $<0.001$ & $1,090(79.4)$ & $157(76.2)$ & $156(78.8)$ & 0.580 \\
\hline & Yes & $661(13.6)$ & $61(25.4)$ & $39(21.8)$ & & $283(20.6)$ & $49(23.8)$ & $42(21.2)$ & \\
\hline \multirow[t]{2}{*}{ Psychological health problems } & No & $4,072(83.5)$ & $175(72.9)$ & $135(75.4)$ & $<0.001$ & 1,093 (79.6) & $158(76.7)$ & $159(80.3)$ & 0.592 \\
\hline & Yes & $803(16.5)$ & $65(27.1)$ & $44(24.6)$ & & $280(20.4)$ & $48(23.3)$ & $39(19.7)$ & \\
\hline \multirow[t]{2}{*}{ Stress } & No & $4,093(84.0)$ & $175(72.9)$ & $137(76.5)$ & $<0.001$ & $1,105(80.5)$ & $158(76.7)$ & 161 (81.3) & 0.406 \\
\hline & Yes & $782(16.0)$ & $65(27.1)$ & $42(23.5)$ & & $268(19.5)$ & $48(23.3)$ & $37(18.7)$ & \\
\hline \multirow[t]{2}{*}{ Sleeping problems } & No & $4,661(95.6)$ & $212(88.3)$ & $162(90.5)$ & $<0.001$ & $1,301(94.8)$ & $194(94.2)$ & $180(90.9)$ & 0.094 \\
\hline & Yes & $214(4.4)$ & $28(11.7)$ & $17(9.5)$ & & $72(5.2)$ & $12(5.8)$ & $18(9.1)$ & \\
\hline \multirow[t]{2}{*}{ Anxiety } & No & 4,708 (96.6) & $216(90.0)$ & 164 (91.6) & $<0.001$ & $1,309(95.3)$ & $196(95.1)$ & $182(91.9)$ & 0.121 \\
\hline & Yes & $167(3.4)$ & $24(10.0)$ & $15(8.4)$ & & $64(4.7)$ & $10(4.9)$ & $16(8.1)$ & \\
\hline \multirow[t]{2}{*}{ Depression } & No & $4,746(97.4)$ & $217(90.4)$ & $168(93.9)$ & $<0.001$ & $1,329(96.8)$ & 197 (95.6) & $184(92.9)$ & 0.025 \\
\hline & Yes & $129(2.6)$ & $23(9.6)$ & $11(6.1)$ & & $44(3.2)$ & $9(4.4)$ & $14(7.1)$ & \\
\hline
\end{tabular}

*Calculated by chi-squared test. 
Table 3 Odds ratios (OR) and $95 \%$ confidence intervals for the association between job insecurity and work-related health problems in temporary workers

\begin{tabular}{|c|c|c|c|c|c|c|}
\hline & \multicolumn{3}{|c|}{$\begin{array}{c}\text { Crude OR } \\
\text { Job insecurity }\end{array}$} & \multicolumn{3}{|c|}{$\begin{array}{l}\text { Adjusted OR* } \\
\text { Job insecurity }\end{array}$} \\
\hline & $\begin{array}{c}\text { Low } \\
\text { OR }(95 \% \mathrm{CI})\end{array}$ & $\begin{array}{l}\text { Moderate } \\
\text { OR }(95 \% \mathrm{Cl})\end{array}$ & $\begin{array}{c}\text { High } \\
\text { OR }(95 \% \mathrm{Cl})\end{array}$ & $\begin{array}{c}\text { Low } \\
\text { OR }(95 \% \mathrm{Cl})\end{array}$ & $\begin{array}{c}\text { Moderate } \\
\text { OR }(95 \% \mathrm{Cl})\end{array}$ & $\begin{array}{c}\text { High } \\
\text { OR }(95 \% \mathrm{Cl})\end{array}$ \\
\hline All health problems & reference & $1.18(0.86-1.62)$ & $0.83(0.59-1.16)$ & reference & $1.16(0.83-1.61)$ & $0.76(0.53-1.09)$ \\
\hline Physical health problems & reference & $1.18(0.86-1.62)$ & $0.86(0.61-1.22)$ & reference & $1.14(0.82-1.60)$ & $0.78(0.54-1.12)$ \\
\hline Backache & reference & $1.33(0.95-1.88)$ & $0.84(0.66-1.40)$ & reference & $1.23(0.86-1.78)$ & $0.85(0.57-1.27)$ \\
\hline Headache & reference & $1.31(0.86-1.99)$ & $0.98(0.61-1.55)$ & reference & $1.22(0.79-1.89)$ & $0.83(0.51-1.35)$ \\
\hline Abdominal pain & reference & $1.08(0.61-1.90)$ & $1.13(0.64-1.99)$ & reference & $0.97(0.53-1.77)$ & $0.96(0.53-1.76)$ \\
\hline Muscular pain & reference & $1.26(0.90-1.76)$ & $1.04(0.73-1.49)$ & reference & $1.21(0.85-1.73)$ & $0.94(0.64-1.36)$ \\
\hline Fatigue & reference & $1.20(0.85-1.70)$ & $1.04(0.72-1.49)$ & reference & $1.23(0.86-1.78)$ & $0.96(0.66-1.42)$ \\
\hline Psychological health problems & reference & $1.19(0.84-1.68)$ & $0.96(0.66-1.39)$ & reference & $1.13(0.78-1.63)$ & $0.88(0.59-1.30)$ \\
\hline Stress & reference & $1.25(0.88-1.78)$ & $0.95(0.65-1.39)$ & reference & $1.19(0.83-1.73)$ & $0.86(0.58-2.10)$ \\
\hline Sleeping problems & reference & $1.12(0.59-2.09)$ & $1.81(1.05-3.09)$ & reference & $1.06(0.56-2.04)$ & $1.75(0.99-3.10)$ \\
\hline Anxiety & reference & $1.04(0.53-2.07)$ & $1.80(1.02-3.18)$ & reference & $0.91(0.45-1.84)$ & $1.72(0.94-3.14)$ \\
\hline Depression & reference & $1.38(0.66-2.87)$ & $2.30(1.24-4.28)$ & reference & $1.28(0.59-2.78)$ & $2.41(1.24-4.68)$ \\
\hline
\end{tabular}

*Adjusted for gender, age, education, income, occupation, smoking, drinking, physical \& chemical hazards, ergonomic risk factor, working hours, and work schedule.

platelet activities, to increase the risk of myocardial ischemia and thrombus formation. This is the reason exposure to stress could contribute to the onset or aggravation of cardiovascular diseases [28]. Sociopsychological factors linked with stress can also increase the degree of muscle tension and thus worsen the biomechanical tension in the musculoskeletal system causing an actual physical disability [29]. Stress also shows a connection to psychological well-being. It is thought to happen as a result of hormone changes such as dopamine and serotonin [30], or to those with a tendency to develop psychiatric diseases, who cannot overcome stress and succumb a full-blown malady [31].

Studies of job insecurity show a wide range of results for the incidence in employees according to the cohort setting (13.2\%-51.2\%) [5,32]. In our study, $11.6 \%$ of respondents at least moderate job insecurity, a result somewhat lower than in other reports. Such an outcome could be

Table 4 Odds ratios (OR) and 95\% confidence intervals for the association between job insecurity and work-related health problems in permanent workers

\begin{tabular}{|c|c|c|c|c|c|c|}
\hline & \multicolumn{3}{|c|}{$\begin{array}{c}\text { Crude OR } \\
\text { Job insecurity }\end{array}$} & \multicolumn{3}{|c|}{$\begin{array}{l}\text { Adjusted OR* } \\
\text { Job insecurity }\end{array}$} \\
\hline & $\begin{array}{c}\text { Low } \\
\text { OR }(95 \% \mathrm{Cl})\end{array}$ & $\begin{array}{l}\text { Moderate } \\
\text { OR }(95 \% \mathrm{Cl})\end{array}$ & $\begin{array}{c}\text { High } \\
\text { OR }(95 \% \mathrm{Cl})\end{array}$ & $\begin{array}{c}\text { Low } \\
\text { OR }(95 \% \mathrm{Cl})\end{array}$ & $\begin{array}{l}\text { Moderate } \\
\text { OR }(95 \% \mathrm{Cl})\end{array}$ & $\begin{array}{c}\text { High } \\
\text { OR }(95 \% \mathrm{Cl})\end{array}$ \\
\hline All health problems & reference & $1.62(1.21-2.15)$ & $1.84(1.34-2.54)$ & reference & $1.57(1.16-2.12)$ & $1.81(1.29-2.55)$ \\
\hline Physical health problems & reference & $1.70(1.28-2.27)$ & $1.83(1.32-2.54)$ & reference & $1.65(1.22-2.23)$ & $1.80(1.28-2.55)$ \\
\hline Backache & reference & $2.21(1.61-3.02)$ & $1.93(1.33-2.81)$ & reference & $2.08(1.49-2.90)$ & $1.78(1.20-2.64)$ \\
\hline Headache & reference & $2.23(1.59-3.14)$ & $1.92(1.28-2.89)$ & reference & $2.19(1.53-3.13)$ & $1.91(1.25-2.93)$ \\
\hline Abdominal pain & reference & $2.65(1.78-3.95)$ & $3.32(2.18-5.06)$ & reference & $2.52(1.66-3.81)$ & $3.27(2.09-5.12)$ \\
\hline Muscular pain & reference & $1.98(1.45-2.69)$ & $1.83(1.27-2.62)$ & reference & $1.86(1.35-2.58)$ & $1.68(1.14-2.46)$ \\
\hline Fatigue & reference & $2.17(1.61-2.94)$ & $1.78(1.23-2.56)$ & reference & $2.12(1.54-2.92)$ & $1.75(1.19-2.57)$ \\
\hline Psychological health problems & reference & $1.88(1.40-2.23)$ & $1.65(1.17-2.34)$ & reference & $1.90(1.39-2.58)$ & $1.69(1.17-2.44)$ \\
\hline Stress & reference & $1.94(1.45-2.61)$ & $1.61(1.13-2.29)$ & reference & $1.97(1.44-2.68)$ & $1.65(1.14-2.40)$ \\
\hline Sleeping problems & reference & $2.88(1.89-4.37)$ & $2.29(1.36-3.84)$ & reference & $3.04(1.95-4.74)$ & $2.31(1.33-4.02)$ \\
\hline Anxiety & reference & $3.13(1.99-4.91)$ & $2.58(1.49-4.47)$ & reference & $2.91(1.82-4.65)$ & $2.33(1.31-4.13)$ \\
\hline Depression & reference & $3.89(2.45-6.20)$ & $2.41(1.28-4.54)$ & reference & $3.82(2.34-6.23)$ & $2.26(1.16-4.39)$ \\
\hline
\end{tabular}


explained by the percentage of temporary workers included in a cohort $[16,17]$, and we concluded that the direct comparison to the cohorts of other studies with different proportions of temporary workers would be impractical.

Our study results show that job insecurity is correlated to health in permanent employees, but not in temporary employees. This result is in accordance to many other reports already published that the job insecurity of permanent workers has a greater correlation to health than that of temporary ones [17]. One theory that explains the hypothesis that job insecurity has a greater impact on the health of permanent employees is the psychological contract theory. A psychological contract is a concept that with the expectations or sense of mutual obligation, one can form obligations to an organization one belongs to and fulfill it, to achieve the right to continue working for that particular organization [33]. In other words, the permanent worker forms a greater psychological contract than the temporary worker. In return for stability, they go as far as to tolerate expectations of the employer and obligations that follow, but as soon as they experience an incident that does not guarantee such stability within the employment arrangement, they tend to feel greater betrayal than the temporary employee, which then to becomes a more impactful stress factor in the form of job insecurity, to finally end in negative consequences to psychological and physical health and well-being [15]. Since the influence of job insecurity in accordance with the type of contract has not been clarified, however, and also whether the amount of work or nature of the work that is known to affect the health of the temporary workers has not been thoroughly analyzed, one cannot prematurely conclude that there is no connection between job insecurity and the work-related health of temporary employees per se.

In our research, job insecurity did not show a clear dose-response relationship in any of absence of related areas. We can assume from this result, that they do not feel either the presence or absence of security altogether but rather experience it on a continuum [3]. However, many previous studies have shown a dose-response curve $[16,17]$, and this shows that there is a need for further studies in this area.

The strength of this study is having a large scale cohort population of 7,071, and that this is a sampling study that extends to the entire country, which can therefore be representative of the national population. In addition, when the survey was performed, well-trained surveyors were engaged, and systematic surveys were used so that random interpretation of the respondents could be prevented to minimize information bias. Also, another strength of this study was that, unlike other studies that focused on only a few symptoms or health problems, our study investigated a variety of work-related health problems.
Our research also has its limitations. Since our study is a cross-sectional study, proving a causal relationship between job insecurity and work-related health. In measuring job insecurity, only one clause was used, and not using the Occupational Stress Scale for Korean Employees [34] that is popularly used in the Korea or the scale of Ashford et al. that is used in many studies in other countries [35] can be considered as a drawback. There is not a generally accepted method of measuring such associations as yet [4], and different studies are using different methods of measurement [2]. The basic concept of such a variety of methods, however, has its cornerstone in understanding whether or not the current work position or employment status could be continued in the near future [4]. The clause in our study also has its foundation on such a concept, and the Fourth European Working Conditions Survey, which is the basis of the survey we have used in our study, has the same clause as a part of its investigation of job insecurity [36]. One meta-analysis also found that more than $30 \%$ of the studies it included used one clause for analysis [2], and our literature review also turned up many studies in which single-clause surveys were used. A question clause about work-related health problems also has its limitations in that as it is a self-reported questionnaire, there could be a disparity in the actual health of the workers from what they reported. Self-report questionnaires, however, are known to be a good predictive tool for the actual health factors, such as mortality [37]. There is also evidence that nationwide scale self-reported questionnaires in general show good reliability [38], and considering there are many studies that have used Working Conditions Survey data, which our study used as the health measurement method $[9,39]$, using the survey in our study did not seem to be a problem. Future studies, however, measuring job insecurity and/or health problems, could use methods that have been proven valid and reliable to overcome the potential limitations of our study. Another limitation is that there is a gap between the known percentage of permanent and temporary workers and the percentage investigated in our study. In the same year that our study was carried out, Statistics Korea had actually determined that the percentage of permanent employees was about $64.5 \%$ through an economic activity survey [40], but the study we carried out found the percentage to be $74.9 \%$, higher than that of Statistics Korea. It seems the difference seen here might be due to the different definitions of the contract type. Statistics Korea's economic activity population survey allows for overlap between types of temporary workers such as part-time work, employment by the hour, and irregular work, but in our study we have described temporary work in its exclusive form [22].

As it is expected that the number of employees experiencing job insecurity will increase consistently with ongoing changes in the labor market, there will be an increasing 
need for research on the health and working conditions in the future. Not only the use of surveys for subjective information, but objective information such as blood pressure measurement or taking blood samples for laboratory examinations is also needed, and research that aims to investigate methods to reduce job insecurity as well as the factors that cause it should be performed at the same time.

\section{Competing interests}

The authors declare that they have no competing interests.

\section{Author's contributions}

WWL and JBP designed the research. MSK collected the data. WWL and KBM performed the statistical analysis. WWL, KLL, and JBP interpreted the data. WWL and KBM wrote the manuscript. All of the authors read and approved the final manuscript.

\section{Author details}

${ }^{1}$ Department of Occupational and Environmental Medicine, Ajou University Hospital, Suwon, South Korea. ${ }^{2}$ Department of Occupational and Environmental Medicine, Ajou University School of Medicine, Suwon, South Korea.

Received: 29 October 2012 Accepted: 8 July 2013

Published: 11 September 2013

\section{References}

1. Ferrie JE: Is job insecurity harmful to health? J R Soc Med 2001, 94:71-76.

2. Sverke $M$, Hellgren J, Näswall K: No security: a meta-analysis and review of job insecurity and its consequences. J Occup Health Psychol 2002, 7(3):242-264.

3. Witte HD: Job Insecurity and psychological well-being: review of the literature and exploration of some unresolved issues. Eur J Work Org Psychol 1999, 8(2):155-177.

4. Sverke $M$, Hellgren J: The nature of job insecurity: Understanding employment uncertainty on the brink of a new millennium. Appl Psychol Int Rev 2002, 51(1):23-42.

5. Burgard SA, Brand JE, House JS: Perceived job insecurity and worker health in the United States. Soc Sci Med 2009, 69(5):777-785.

6. De Witte H: Job insecurity: review of the international literature on definitions, prevalence, antecedents and consequences. SA J Ind Psychol 2007, 31(4):1-6.

7. Laszlo KD, Pikhart H, Kopp MS, Bobak M, Pajak A, Malyutina S, Salavecz G, Marmot M: Job insecurity and health: a study of 16 European countries. Soc Sci Med 2010, 70(6):867-874.

8. Muenster E, Rueger H, Ochsmann E, Letzel S, Toschke AM: Association between overweight, obesity and self-perceived job insecurity in German employees. BMC Publ Health 2011, 11:162.

9. Park JB, Nakata A, Swanson NG, Chun H: Organizational factors associated with work-related sleep problems in a nationally representative sample of Korean workers. Int Arch Occup Environ Health 2013, 86(2):211-222.

10. Park KC, Lee KJ, Park JB, Min KB, Lee KY: Association between occupational stress and depression, anxiety, and stress symptoms among white-collar male workers in an automotive company. Korean J Occup Environ Med 2008, 20(3):215-224.

11. Kim TW, Kim KS, Ahn YS: Relationship between job stress and depressive symptoms among field firefighters. Korean J Occup Environ Med 2010, 22(4):378-387.

12. Yu KY, Lee KJ, Min KB, Park KC, Chai SK, Park JB: Association between job stress and mental health among workers in a large company. J Korean Soc Occup Environ Hyg 2011, 21(3):146-155.

13. Koo H: Nonstandard employee's employment insecurity and organizational commitment: a comparative study. Korean J Soc 2005, 39(2):163-195

14. De Witte $H$, Näswall K: 'Objective' vs 'subjective' job Insecurity: consequences of temporary work for job satisfaction and organizational commitment in four european countries. Econ Ind Democracy 2003, 24(2):149-188.
15. De Cuyper N, De Witte H: Job insecurity in temporary versus permanent workers: associations with attitudes, well-being, and behaviour. Work Stress 2007, 21(1):65-84.

16. Virtanen $P$, Janlert $U$, Hammarstrom A: Exposure to temporary employment and job insecurity: a longitudinal study of the health effects. Occup Environ Med 2011, 68(8):570-574.

17. Kirves K, De Cuyper N, Kinnunen U, Natti J: Perceived job insecurity and perceived employability in relation to temporary and permanent workers' psychological symptoms: a two samples study. Int Arch Occup Environ Health 2011, 84(8):899-909.

18. Hesselink DK, Van Vuuren T: Job flexibility and job insecurity: the Dutch case. Eur J Work Org Psychol 1999, 8(2):273-293.

19. De Cuyper N, De Witte H: Job insecurity: mediator or moderator of the relationship between type of contract and various outcomes? SA J Ind Psychol 2007, 31(4):79-86.

20. Cuyper N, Witte $H$ : The impact of job insecurity and contract type on attitudes, well-being and behavioural reports: a psychological contract perspective. J Occup Organ Psychol 2006, 79(3):395-409.

21. Bernhard-Oettel C, Sverke M, De Witte H: Comparing three alternative types of employment with permanent full-time work: how do employment contract and perceived job conditions relate to health complaints? Work Stress 2005, 19(4):301-318.

22. Occupational Safety \& Health Research Institute: National sample survey of working condition survey \& occupational disease health-risk-factor on employee. Incheon; 2006.

23. Ferrie JE, Shipley MJ, Newman K, Stansfeld SA, Marmot M: Self-reported job insecurity and health in the Whitehall II study: potential explanations of the relationship. Soc Sci Med 2005, 60(7):1593-1602.

24. Heaney CA, Israel BA, House JS: Chronic job insecurity among automobile workers: effects on job satisfaction and health. Soc Sci Med 1994, 38(10):1431-1437.

25. Kim DH, Park SG, Kim HC, Lee EC, Kim JH, Leem JH: The relationship between job stress and the common cold. Korean J Occup Environ Med 2008, 20(2):74-80.

26. Lee $\mathrm{S}$, Colditz GA, Berkman LF, Kawachi I: Prospective study of job insecurity and coronary heart disease in US women. Ann Epidemiol 2004, 14:24.

27. Dougal AL, Baum A: Stress, Health and IIIness. In Handbook of health psychology. 2nd edition. Edited by Baum A, Revenson TA, Singer J. New York: Psychology; 2011:321-337.

28. Rozanski A, Bairey CN, Krantz DS, Friedman J, Resser KJ, Morell M, HiltonChalfen S, Hestrin L, Bietendorf J, Berman DS: Mental stress and the induction of silent myocardial ischemia in patients with coronary artery disease. N Engl J Med 1988, 318(16):1005-1012.

29. Bernard B, Sauter S, Fine L, Petersen M, Hales T: Job task and psychosocial risk factors for work-related musculoskeletal disorders among newspaper employees. Scand J Work Environ Health 1994, 20(6):417-426.

30. Myint AM, Kim YK: Cytokine-serotonin interaction through IDO: a neurodegeneration hypothesis of depression. Med hypotheses 2003, 61(5-6):519-525.

31. Heim C, Nemeroff CB: The impact of early adverse experiences on brain systems involved in the pathophysiology of anxiety and affective disorders. Biol Psychiatry 1999, 46(11):1509-1522.

32. Cheng Y, Chen CW, Chen CJ, Chiang TL: Job insecurity and its association with health among employees in the Taiwanese general population. Soc Sci Med 2005, 61(1):41-52.

33. Guest D: Flexible employment contracts, the psychological contract and employee outcomes: an analysis and review of the evidence. Int J Manag Rev 2004, 5(1):1-19.

34. Chang SJ, Koh SB, Kang D, Kim SA, Kang MG, Lee CG, Chung JJ, Cho JJ, Son M, Chae CH, Kim JW, Kim JI, Kim HS, Roh SC, Park JB, Woo JM, Kim SY, Kim JY, Ha M, Park J, Rhee KY, Kim HR, Kong JO, Kim IA, Kim JS, Park JH, Huyun SJ, Son DK: Developing an occupational stress scale for Korean employees. Korean J Occup Environ Med 2005, 17(4):297-317.

35. Ashford SJ, Lee C, Boboko P: Content, cause, and consequences of job insecurity: a theory-based measure and substantive test. Acad Manag j 1989, 32(4):803-829. 
36. European Foundation for the Improvement of Living and Working Conditions: Fourth European working condition survey. Dublin; 2007.

37. Burström B, Fredlund P: Self rated health: is it as good a predictor of subsequent mortality among adults in lower as well as in higher social classes? J Epidemiol Community Health 2001, 55(11):836-840.

38. Crossley TF, Kennedy S: The reliability of self-assessed health status. $J$ Health Econ 2002, 21(4):643-658.

39. Park J, Yi Y, Kim Y: Weekly work hours and stress complaints of workers in Korea. Am J Ind Med 2010, 53(11):1135-1141.

40. Economically active population survey. http://kosis.kr/nsikor/view/stat10.do.

doi:10.1186/2052-4374-25-15

Cite this article as: Lee et al:: Association between work-related health problems and job insecurity in permanent and temporary employees. Annals of Occupational and Environmental Medicine 2013 25:15.

\section{Submit your next manuscript to BioMed Central and take full advantage of:}

- Convenient online submission

- Thorough peer review

- No space constraints or color figure charges

- Immediate publication on acceptance

- Inclusion in PubMed, CAS, Scopus and Google Scholar

- Research which is freely available for redistribution 